\title{
PDZK1IP1 wt Allele
}

National Cancer Institute

\section{Source}

National Cancer Institute. PDZK1IP1 wt Allele. NCI Thesaurus. Code C52371.

Human PDZK1IP1 wild-type allele is located within 1p33 and is approximately $7 \mathrm{~kb}$ in length. This allele, which encodes PDZK1-interacting protein 1, plays a role in plasma membrane interactions. 